\title{
Meta Analisis Penerapan Model Pembelajaran Problem Based Learning Terhadap Motivasi Belajar
}

\section{Rizki Wahyuningtyas ${ }^{1 *}$, Firosalia Kristin ${ }^{2}$}

${ }^{12}$ Jurusan Pendidikan Guru Sekolah Dasar, Universitas Kristen Satya Wacana, Salatiga, Indonesia

\author{
A R T I C LEINFO \\ Article history: \\ Received 1 Januari 2021 \\ Received in revised form \\ 30 Januari 2021 \\ Accepted 1 Maret 2021 \\ Available online 8 April \\ 2021 \\ Kata Kunci: \\ problem based learning, \\ motivasi belajar \\ Keywords: \\ problem based learning, \\ learning motivation
}

\begin{abstract}
A B S T R A K
Penelitian ini dilakukan karena banyaknya peserta didik mendapat hasil belajar kurang memuaskan yang diduga karena kurangnya motivasi dalam belajar. Selain itu, Penelitian ini juga memiliki tujuan guna menganalisis kembali penerapan model pembelajaran Problem based learning dalam meningkatkan motivasi belajar peserta didik sekolah dasar. Metode yang digunakan penulis dalam penelitian ini yaitu metode meta analisis. Penulis mengawali penelitian ini dengan mencari topik yang relevan guna memudahkan penulis dalam mengumpulkan data. Data tersebut diperoleh dengan cara menelusuri jurnal-jurnal online melalui google academia dengan kata kunci Problem based learning, Meningkatkan Motivasi Belajar, Sekolah Dasar. Dari penelusuran yang dilakukan diperoleh 25 artikel tetapi yang relevan untuk digunakam hanya 15 artikel. Data-data yang telah diperoleh diolah kembali menggunakan metode kuantitatif. Berdasarkan hasil analisis penggunaan model pembelajaran Problem based learning dalam pembelajaran terbukti dapat meningkatkan Motivasi Belajar Peserta Didik paling rendah $7,1 \%$ dan yang paling tinggi $52,69 \%$. Penggunaan Problem
\end{abstract} based learning sangat berpengaruh terhadap motivasi belajar peserta didik. Selain itu peserta didik juga mempunyai pengalaman yang berbeda dalam proses pembelajaran karena dituntut untuk menyelesaikan permasalahan yang ada. Hal ini juga dapat meningkatkan kemampuan siswa dalam memahami materi pelajaran dengan mudah selama proses pembelajaran.

\begin{abstract}
A B S T R A C T
This research was conducted because the large number of students got unsatisfactory learning outcomes which was thought to be due to a lack of motivation in learning. In addition, this study also aims to re-analyze the application of problem-based learning models in increasing learning motivation of elementary school students. The method used by the writer in this research is meta-analysis method. The author begins this research by looking for relevant topics to make it easier for the author to collect data. The data was obtained by searching online journals through google academia with the keywords Problem based learning, Increasing Learning Motivation, Elementary School. From the search conducted, it was obtained 25 articles, but only 15 articles were relevant to use. The data that has been obtained are reprocessed using quantitative methods. Based on the results of the analysis of using the problem-based learning model in learning, it is proven that it can increase the students' motivation to learn at the lowest $7.1 \%$ and the highest $52.69 \%$. The use of problem based learning is very influential on the learning motivation of students. In addition, students also have different experiences in the learning process because they are required to solve existing problems. It can also improve students' ability to understand subject matter easily during the learning process.
\end{abstract}

\section{Pendahuluan}

Motivasi belajar adalah salah satu faktor yang sangat penting dalam proses pembelajaran. Motivasi belajar adalah dorongan dari dalam diri siswa untuk melakukan sesuatu secara sungguhsungguh sampai apa yang menjadi harapannya bisa tercapai (Sugianto, 2019; Susiana \& Wening, 2015). Munculnya motivasi akan mempengaruhi hasil belajar siswa (Maryoto, 2018; Putri Ningrat et 
al., 2018; Shoffa \& Suprapti, 2017). Motivasi belajar yang tinggi akan akan berdampak terhadap peningkatan hasil belajar (Mulyasih \& Suryani, 2016; Saputra et al., 2018; Suprapto, 2017). Motivasi belajar yang memadai akan mendorong siswa berperilaku aktif untuk berprestasi dalam kelas, tetapi motivasi yang terlalu kuat justru dapat berpengaruh negatif terhadap keefektifan usaha belajar siswa (Fauziah et al., 2017). Pentingnya motivasi siswa dalam proses pembelajaran menuntut peran guru untuk merancang pembelajaran yang mempu menumbuhkan motivasi siswa dalam belajar, serta menciptakan suasana pembelajaran yang menarik dan menyenangkan (Ayuwanti, 2017). Dalam merancang pembelajaran tentunya tidak bisa terlepas dari model pembelajaran. Adanya model pembelajaran dapat menumbuhkan motivasi belajar (Kurniawan \& Wuryandani, 2017; Ulya \& Irawati, 2016). Penggunaan model pembelajaran inovatif akan mambuat proses pembelajaran lebih menyenangkan serta mampu membuat siswa lebih aktif sehingga siswa mendapatkan pengalaman yang lebih banyak, yang membuat pembelajaran lebih bermakna (Angela, 2014; Kostiainen et al., 2018). Oleh sebab itu, guru sebaiknya menerapkan pembelajaran sesuai karakteristik siswa SD serta menekankan aktivitas peserta didik baik aktivitas mengevaluasi dan menganalisis apa yang dipelajarinya (Haryanti, 2017).

Namun, saat ini harapan masih belum sesaui denga napa yang dicita-ciatakan, dimana proses pembelajaran terbatas pada penyampaian materi oleh pendidik dan pemberian latihan soal, sehingga motivasi belajar peserta didik rendah (Sari \& Sugiyarto, 2015). Pembelajaran lebih banyak menggunakan metode ceramah dan lebih banyak berpusat kepada guru, dan mengurangi aktifitas siswa dalam proses pembelajaran. Penggunaan metode tersebut membuat siswa jenuh dan kurang tertarik dalam belajar serta kehilangan motivasi belajar (Astuti et al., 2020; Mawaddah et al., 2019). Kurangnya motivasi siswa dalam proses pembelajaran akan mempengaruhi hasil belajar. Kondisi saat ini hasil belajar siswa SD masih belum sesuai dengan yang diaharapakan dan lebih cendrung rendah (Adnyani et al., 2020). Jika masalah ini dibiarkan begitu saja akan berdampak terhadap kualitas sumber daya masnusia yang dihasilkan. Salah satu solusi yang digunakan adalah dengan menerapkan model pemelajaran inovatif. Salah satu model pembelajaran inovatif adalah model problem-based learning.

Model problem-based learning adalah salah satu model pembelajaran yang berpusat pada siswa. model pembelajaran problem-based learning membuat proses pembelajaran lebih aktif karena siswa aktif menemukan pemecahan masalah yang diberikan (Dewi et al., 2016; Widodo \& Widayanti, 2014). Dengan siswa aktif dalam proses pembelajaran mampu meningkatkan hasil belajarnya (Darmawan \& Harjono, 2020). Serta, PBL dapat meningkatkan keterampilan sosial siswa (Dewi et al., 2016), mengembangkan keterampilan, menyelesaikan masalah, dan berpikir kritis serta dapat bekerja sama dalam memecahkan permasalahan (Andari et al., 2019; Supiandi \& Julung, 2016). Jabaranjabaran ini membuat beberapa peneliti sudah melakukan penelitian tentang efektifitas model pembelajaran PBL terhadap proses pembelajan. Beberapa penelitian yang sudah dilakukan antara lain Juliawan et al., (2017) menunjukkan bahwa problem based learning (PBL) berpengaruh positif terhadap kemampuan pemecahan masalah matematika siswa. Kusumayanti et al., (2017)menyatakan bahwa Problem Based Learning berbantuan media audio terhadap penguasaan kompetensi pengetahuan IPS siswa kelas V SD. Usman \& Afriansyah, (2017) menayakan bahwa terdapat perbedaan kemampuan pemahaman matematis antara siswa yang mendapatkan model pembelajaran AIR dengan PBL. Lin, (2015) menyatakan bahwa PBL dapat meningkatkan kemampuan kosa kata siswa. Jadi, adanya model pembelajaran PBL sudah sangat berdampak terhadap pembelajaran. Walupuan sudah dilakukan beberapa penelitian namun tetep saja hal ini belum mampu mengoptimalkan pembelajaran.

Hal inilah menjadi salah satu alasan mengapa penelitian yang bertujuan untuk mengkaji efektivitas model pembelajaran problem-based learning (PBL) terhadap motivasi belajar siswa melalui kajian meta analisis. Dengan adanya penelitia ini diaharapakan memberikan kajian yang jelas tentang efektivitas pembelajaran dengan model PBL yang selama ini dilakukan.

\section{Metode}

Penelitian ini menggunkan metode meta analisis. Meta analisis yaitu penelitian yang dilakukan dengan cara merangkum, mereview dan menganalis data penelitian dari hasil penelitian sebelumnya. Jadi secara sederhana meta analisis yaitu pengkajian ulang terhadap hasil-hasil penelitian sejenis yang 
sudah ada. Meta analisis merupakan salah satu cara membuat rangkuman hasil penelitian secara kuantitatif. Instrumen yang digunakan dalam penelitian ini yaitu artikel jurnal. Pengumpulan data dalam penelitian ini dilakukan dengan cara mencari jurnal pada media elektronik. Pencarian jurnal dilakukan melalui Google Academia dengan menggunakan kata kunci model pembelajaran Problem based learning, Motivasi Belajar, Sekolah Dasar. Berdasarkan penelusuran di Google Scholar didapat 25 artikel yang sesuai dengan judul yang akan diteliti dan dipilih 12 yang relevan . Naskah yang dikaji penulis merupakan hasil dari penelitian Eksperimen sehingga memiliki data nilai sebelum dan sesudah perlakuan. Penulis melakukan kajian dengan menggunakan metode pembandingan untuk mengetahui dampak penggunaan model pembelajaran Problem based learning berbasis selisih skor motivasi belajar peserta didik sebelum dan sesudah tindakan.

\section{Hasil dan Pembahasan}

Penelitian yang bertujuan mengkaji efektivitas model pembelajaran problem-based learning (PBL) terhadap motivasi belajar siswa melalui kajian meta analisis. Penelitian ini membandingkan 12 artikel yang sudah memenuhi syarat. Hasil perbandingan artikel-artikel yang digunakan sebagai sampel penelitian ini ditunjukkan pada tabel 1 berikut.

Tabel 1. Peningkatan Motivasi Belajar

\begin{tabular}{|c|c|c|c|c|c|c|}
\hline \multirow[t]{2}{*}{ No } & \multirow[t]{2}{*}{ Topik Penelitian } & \multirow[t]{2}{*}{ Peneliti } & \multicolumn{4}{|c|}{ Peningkatan Hasil Belajar } \\
\hline & & & Sebelum & Sesudah & Gain & Gain\% \\
\hline 1. & $\begin{array}{l}\text { Pengaruh Model Problem } \\
\text { based learning Terhadap } \\
\text { Motivasi Belajar IPA Siswa } \\
\text { Kelas V SDN Gadingan }\end{array}$ & Rini Istanti & 66,93 & 81,82 & 14,89 & 22,24 \\
\hline 2. & $\begin{array}{c}\text { Pengaruh Penggunaan } \\
\text { Model Problem based } \\
\text { learning (PBL) Terhadap } \\
\text { Motivasi Belajar } \\
\text { Matematika pada Siswa } \\
\text { Kelas 4 SD }\end{array}$ & $\begin{array}{c}\text { Tomas dan } \\
\text { Tego }\end{array}$ & 37,33 & 57,00 & 19,67 & 52,69 \\
\hline 3. & $\begin{array}{c}\text { Meningkatkan Motivasi } \\
\text { Belajar Melalui } \\
\text { Pendekatan Problem based } \\
\text { learning (PBL) }\end{array}$ & $\begin{array}{l}\text { Habibah, } \\
\text { Maulana dan } \\
\text { Ali }\end{array}$ & 82,91 & 90,10 & 7.19 & 8,67 \\
\hline 4. & $\begin{array}{c}\text { Pengaruh Model PBL } \\
\text { (Problem based learning) } \\
\text { terhadap Motivasi dan } \\
\text { Hasil Belajar IPA Peserta } \\
\text { Didik }\end{array}$ & $\begin{array}{l}\text { Ramlawati, } \\
\text { Sitti dan } \\
\text { Aunillah }\end{array}$ & 84,36 & 105,6 & 21,24 & 25,17 \\
\hline 5. & $\begin{array}{c}\text { Pengaruh Pembelajaran } \\
\text { Berbasis Masalah } \\
\text { Terhadap Motivasi Belajar } \\
\text { dan Prestasi Belajar } \\
\text { Matematika Siswa Kelas VI } \\
\text { SD Gugus II Kecamatan } \\
\text { Tejakula Tahun Pelajaran } \\
\text { 2014/2015 }\end{array}$ & $\begin{array}{l}\text { Ni Kadek, } \\
\text { Nyoman dan I } \\
\text { Made }\end{array}$ & 99,69 & 124,18 & 24.49 & 24,56 \\
\hline 6. & $\begin{array}{c}\text { Pengaruh Pembelajaran } \\
\text { Berbasis Masalah } \\
\text { Terhadap Motivasi Belajar } \\
\text { dan Prestasi Belajar } \\
\text { Matematika Siswa Kelas IV } \\
\text { SD }\end{array}$ & $\begin{array}{l}\text { Pradnyana, } \\
\text { Marhaeni dan } \\
\text { Candisa }\end{array}$ & 100,38 & 109,91 & 9,53 & 9,49 \\
\hline
\end{tabular}




\begin{tabular}{|c|c|c|c|c|c|c|}
\hline \multirow[t]{2}{*}{ No } & \multirow[t]{2}{*}{ Topik Penelitian } & \multirow[t]{2}{*}{ Peneliti } & \multicolumn{4}{|c|}{ Peningkatan Hasil Belajar } \\
\hline & & & Sebelum & Sesudah & Gain & Gain\% \\
\hline 7. & $\begin{array}{c}\text { Pengaruh Model } \\
\text { Pembelajaran Problem } \\
\text { based learning Terhadap } \\
\text { Motivasi Belajar IPA Siswa } \\
\text { Kelas V SD di Gugus } 1 \\
\text { Kecamatan Buleleng }\end{array}$ & $\begin{array}{l}\text { Ni Luh } \\
\text { Heppy, I } \\
\text { Dewa dan I } \\
\text { Wayan }\end{array}$ & 89,29 & 124 & 34,71 & 38,87 \\
\hline 8. & $\begin{array}{c}\text { Pengaruh Model } \\
\text { Pembelajaran Problem } \\
\text { based learning dan } \\
\text { Motivasi Belajar Terhadap } \\
\text { Hasil Belajar Sains Siswa } \\
\text { SD }\end{array}$ & Selvianus & 66,65 & 81,60 & 14,95 & 22,43 \\
\hline 9. & $\begin{array}{c}\text { Efektifitas Pembelajaran } \\
\text { Tematik PPBL-TPS } \\
\text { Terhadap Motivasi Belajar } \\
\text { Peserta Didik }\end{array}$ & $\begin{array}{c}\text { Kinasih Sekar } \\
\text { Tanjung dan } \\
\text { Naniek } \\
\text { Sulistya } \\
\text { Wardani }\end{array}$ & 50 & 66,7 & 16,7 & 33,4 \\
\hline 10. & $\begin{array}{c}\text { Efektivitas Model Problem } \\
\text { based learning Berbantuan } \\
\text { Media Audio-Visual } \\
\text { Terhadap Motivasi dan } \\
\text { Hasil Belajar Siswa pada } \\
\text { Materi Ekskresi }\end{array}$ & $\begin{array}{c}\text { Ragilia } \\
\text { Novitasari, } \\
\text { Yustinus } \\
\text { Ulung } \\
\text { Anggraito, } \\
\text { dan Sri } \\
\text { Ngabekti }\end{array}$ & 91 & 100 & 9 & 9,89 \\
\hline 11. & $\begin{array}{l}\text { Keefektifan PBL dan IBL } \\
\text { Ditinjau dari Prestasi } \\
\text { Belajar, Kemampuan } \\
\text { Representasi Matematis, } \\
\text { dan Motivasi Belajar }\end{array}$ & $\begin{array}{l}\text { Muhamad } \\
\text { Farhan dan } \\
\text { Heri } \\
\text { Renawati }\end{array}$ & 89,47 & 121,33 & 31,86 & 35,6 \\
\hline 12. & $\begin{array}{c}\text { Meningkatkan } \\
\text { Kemampuan Koneksi } \\
\text { Matematik dan Motivasi } \\
\text { Belajar Siswa SMP dengan } \\
\text { Menggunakan Pendekatan } \\
\text { Problem based learning }\end{array}$ & $\begin{array}{l}\text { Angela, } \\
\text { M.Rizqi, } \\
\text { Masta dan } \\
\text { Heris }\end{array}$ & 80,41 & 86,2 & 5,78 & 7,1 \\
\hline & $\begin{array}{r}\text { ata-rata Pembelajaran Me } \\
\text { Problem based learn }\end{array}$ & gunakan & 78,20 & 95,70 & 17,50 & 24,17 \\
\hline
\end{tabular}

Dari 12 sampel artikel menunjukkan besarnya pengaruh penggunaan model pembelajaran Problem based learning. Berdasarkan data yang terdapat pada tabel 1 ternyata penggunaan model pembelajaran Problem based learning dalam pembelajaran mampu meningkatkan motivasi belajar, mulai dari yang terendah 7,1\% sampai yang tertinggi 52,69\%. Berdasarkan hasil analisis data pada tabel 1 rata-rata skor sebelum tindakan yaitu 78,20. Sedangkan rata-rata skor setelah tindakan yaitu 95,70. Selisih rata-rata skor sebelum dan sesudah tindakan yaitu 16,97. Dari data pada tabel 1 dapat dilihat rata-rata gain\% yaitu 24,17\%. Penggunaan model pembelajaran Problem Based Learning dapat menjadi solusi efektif yang dapat digunakan guru untuk meningkatkan motivasi belajar peserta didik.

Penggunaan model pembelajaran Problem based learning dalam pembelajaran menjadi solusi efektif yang dapat digunakan guru untuk meningkatkan motivasi belajar peserta didik. Hal ini dikatakan efektif karena dapat menjadikan proses belajar mengajar menjadi menyenangkan dan tidak monoton sehingga menarik perhatian peserta didik dalam mengikuti pembelajaran sehingga tumbuh motivasi belajar dalam diri peserta didik. Model problem-based learning adalah salah satu model pembelajaran yang berpusat pada siswa. model pembelajaran problem-based learning membuat proses pembelajaran lebih aktif karena siswa aktif menemukan pemecahan masalah yang diberikan 
(Dewi et al., 2016; Widodo \& Widayanti, 2014). Dengan siswa aktif dalam proses pembelajaran mampu meningkatkan hasil belajarnya (Darmawan \& Harjono, 2020). Serta, PBL dapat meningkatkan keterampilan sosial siswa (Dewi et al., 2016), mengembangkan keterampilan, menyelesaikan masalah, dan berpikir kritis serta dapat bekerja sama dalam memecahkan permasalahan (Andari et al., 2019; Supiandi \& Julung, 2016). Dengan pemberian masalah yang ditemuinya dalam kehidupan sehari-hari membuat siswa terdorong untuk belajar dan meningkatakan motivasinya untuk belajar. Jadi, model pembelajaran Problem based learning dapat memfasilitasi peserta didik untuk berperan aktif dalam pembelajaran sehingga mampu mengaktifkan motivasi belajar peserta didik. Motivasi belajar adalah salah satu faktor yang sangat penting dalam proses pembelajaran.

Motivasi belajar adalah dorongan dari dalam diri siswa untuk melakukan sesuatu secara sungguh-sungguh sampai apa yang menjadi harapannya bisa tercapai (Sugianto, 2019; Susiana \& Wening, 2015). Munculnya motivasi akan mempengaruhi hasil belajar siswa (Maryoto, 2018; Putri Ningrat et al., 2018; Shoffa \& Suprapti, 2017). Motivasi belajar yang tinggi akan akan berdampak terhadap peningkatan hasil belajar (Mulyasih \& Suryani, 2016; Saputra et al., 2018; Suprapto, 2017). Motivasi belajar yang memadai akan mendorong siswa berperilaku aktif untuk berprestasi dalam kelas, tetapi motivasi yang terlalu kuat justru dapat berpengaruh negatif terhadap keefektifan usaha belajar siswa (Fauziah et al., 2017). Beberapa penelitian yang sudah dilakukan dan mendukung pernyataan ini adalah antara lain Juliawan et al., (2017) menunjukkan bahwa problem based learning (PBL) berpengaruh positif terhadap kemampuan pemecahan masalah matematika siswa. Kusumayanti et al., (2017) menyatakan bahwa Problem Based Learning berbantuan media audio terhadap penguasaan kompetensi pengetahuan IPS siswa kelas V SD. Usman \& Afriansyah, (2017) menayakan bahwa terdapat perbedaan kemampuan pemahaman matematis antara siswa yang mendapatkan model pembelajaran AIR dengan PBL. Lin, (2015) menyatakan bahwa PBL dapat meningkatkan kemampuan kosa kata siswa. Jadi, adanya model pembelajaran PBL sudah sangat berdampak terhadap pembelajaran.

\section{Simpulan}

Berdasarkan hasil penelitian meta analisis di atas, dapat ditarik kesimpulan bahwa model pembelajaran Problem based learning dapat meningkatkan motivasi belajar peserta didik sekolah dasar. Adanya peningkatan motivasi belajar peserta didik mulai dari yang terendah sampai yang tertinggi. Selain itu dapat juga dilihat dari adanya kenaikan rata-rata skor sebelum tindakan dan ratarata skor setelah tindakan.

\section{Daftar Pustaka}

Adnyani, N. K. M., Pudjawan, K., \& Japa, I. G. N. (2020). Motivasi dan Hasil Belajar IPA dalam Pembelajaran Scramble Berbantuan Kartu Pertanyaan. Jurnal Ilmiah Sekolah Dasar, 4(2), 270. https://doi.org/10.23887/jisd.v4i2.25622

Andari, I. A. K. M. L., Darsana, I. W., \& Asri, A. S. (2019). Pengaruh Model Problem Based Learning (PBL) Berbasis Portofolio Terhadap Hasil Belajar IPS. International Journal of Elementary Education, 2(2), 70. https://doi.org/10.23887/jet.v2i2.16184

Angela, T. (2014). Challenges to Meaningful Learning in Social Studies - The Key Competences as an Opportunity to Students' Active Participation. Procedia - Social and Behavioral Sciences, 128, 192-197. https://doi.org/10.1016/j.sbspro.2014.03.142

Astuti, J., Novita, M., \& Ismail, M. S. (2020). Peningkatan Motivasi Belajar Menggunakan Contextual Teaching and Learning di Madrasah Ibtidaiyah Swasta Raudhatul Mujawwidin Tebo. Jurnal Educative, 5(1). https://doi.org/http://dx.doi.org/10.30983/educative.v5i1.1630

Ayuwanti, I. (2017). Meningkatkan Aktivitas dan Hasil Belajar Matematika Menggunakan Model Pembelajaran Kooperatif Tipe Group Investigation di SMK Tuma'ninah Yasin Metro. SAP (Susunan Artikel Pendidikan), 1(2), 105-114. https://doi.org/10.30998/sap.v1i2.1017

Darmawan, W., \& Harjono, N. (2020). Efektivitas Problem Based Learning dan Two Stay Two Stray dalam Pencapaian Hasil Belajar. Jurnal Basicedu, 4(2), 402-411. 
https://doi.org/10.31004/basicedu.v4i2.364

Dewi, S., Sumarmi, S., \& Amirudin, A. (2016). Penerapan Model Pembelajaran Problem Based Learning Untuk Meningkatkan Keaktifan Dan Keterampilan Sosial Siswa Kelas V Sdn Tangkil 01 Wlingi. Jurnal Pendidikan - Teori, Penelitian, Dan Pengembangan, 1(3), 281-288. https://doi.org/10.17977/jp.v1i3.6148

Fauziah, A., Rosnaningsih, A., \& Azhar, S. (2017). Hubungan Antara Motivasi Belajar Dengan Minat Belajar Siswa Kelas Iv Sdn Poris Gaga 05 Kota Tangerang. Jurnal JPSD Uurnal Pendidikan Sekolah Dasar), 4(1), 47. https://doi.org/10.26555/jpsd.v4i1.a9594

Haryanti, Y. D. (2017). Model Problem Based Learning Membangun Kemampuan Berpikir Kritis Siswa Sekolah Dasar. Jurnal Cakrawala Pendas, 3(2). https://doi.org/10.31949/jcp.v3i2.596

Juliawan, G. A., Mahadewi, L. P. P., \& Rati, W. R. (2017). Pengaruh Model Problem Based Learning (PBL) Terhadap Kemampuan Pemecahan Masalah Matematika. Mimbar PGSD, 5(2), 1-10. https://doi.org/http://dx.doi.org/10.23887/jjpgsd.v5i2.10881

Kostiainen, E., Ukskoski, T., Ruohotie-Lyhty, M., Kauppinen, M., Kainulainen, J., \& Mäkinen, T. (2018). Meaningful learning in teacher education. Teaching and Teacher Education, 71, 66-77. https://doi.org/10.1016/j.tate.2017.12.009

Kurniawan, M. W., \& Wuryandani, W. (2017). Pengaruh model pembelajaran berbasis masalah terhadap motivasi belajar dan hasil belajar PPKn. Jurnal Civics: Media Kajian Kewarganegaraan, 14(1), 10-22. https://doi.org/10.21831/civics.v14i1.14558

Kusumayanti, N. P. C., Asri, I. G. A. A. S., \& Putra, D. K. N. S. (2017). Pengaruh Model Pembelajaran Problem Based Learning Berbantuan Audio Visual Terhadap Kompetensi Pengetahuan IPS Siswa Kelas V. Mimbar PGSD Universitas Pendidikan Ganesha, 5(2), 1-10. https://doi.org/10.23887/jisd.v2i2.15494

Lin, L. F. (2015). The impact of problem-based learning on Chinese-speaking elementary school students' English vocabulary learning and use. System, 55, 30-42. https://doi.org/10.1016/j.system.2015.08.004

Maryoto, G. (2018). Pengaruh Pembelajaran Kooperatif Tipe Think-Pair-Share (Tps) Dan NumberedHeads-Together (Nht) Terhadap Motivasi Dan Hasil Belajar Matematika. Jurnal Pendidikan, 17(2), 121-128. https://doi.org/10.33830/jp.v17i2.271.2016

Mawaddah, W., Ahied, M., Hadi, W. P., Yuniasti, A., \& Wulandari, R. (2019). Uji Kelayakan Multimedia Interaktif Berbasis Powerpoint Disertai Permainan Jeopardy Terhadap Motivasi Belajar Siswa. Natural Science Education Reseach, 2(2), 2654-4210. https://ecoentrepreneur.trunojoyo.ac.id/nser/article/view/6254

Mulyasih, P. S., \& Suryani, N. (2016). Pengaruh Disiplin Belajar, Lingkungan Keluarga, Dan Motivasi Belajar Terhadap Prestasi Belajar Mata Pelajaran Pengantar Administrasi. Economic Education Analysis Journal, 5(2), 602-602. https://doi.org/http://journal.unnes.ac.id/sju/index.php/eea

Putri Ningrat, S., Tegeh, I. M., \& Sumantri, M. (2018). Kontribusi Gaya Belajar Dan Motivasi Belajar Terhadap Hasil Belajar Bahasa Indonesia. Jurnal Ilmiah Sekolah Dasar, 2(3), 257. https://doi.org/10.23887/jisd.v2i3.16140

Saputra, H. D., Ismet, F., \& Andrizal, A. (2018). Pengaruh Motivasi Terhadap Hasil Belajar Siswa SMK. INVOTEK: Jurnal Inovasi Vokasional Dan Teknologi, 18(1), 25-30. https://doi.org/10.24036/invotek.v18i1.168

Sari, D. S., \& Sugiyarto, K. H. (2015). Pengembangan Multimedia Berbasis Masalah Untuk Meningkatkan Motivasi Belajar Dan Kemampuan Berpikir Kritis Siswa. Jurnal Inovasi Pendidikan IPA, 1(2), 153. https://doi.org/10.21831/jipi.v1i2.7501

Shoffa, S., \& Suprapti, E. (2017). Peningkatan Hasil Belajar Mahasiswa pada Mata Kuliah Metode Numerik dengan Model Pembelajaran Kooperatif Jigsaw. MUST: Journal of Mathematics Education, Science and Technology, 2(2), 178-188. http://journal.um- 
surabaya.ac.id/index.php/matematika/article/view/736

Sugianto, P. A. W. (2019). Penerapan Model pembelajaran VPS dengan Bantuan Modul Elektronik Terhadap Motivasi Belajar dan Kempuan Berpikir Kreatif di SMA Negeri 8 PekanBaru 2017. Journal of Chemical Information and Modeling, 53(9), 1689-1699. https://doi.org/10.1017/CB09781107415324.004

Supiandi, M. I., \& Julung, H. (2016). Pengaruh Model Problem Based Learning (PBL) terhadap Kemampuan Memecahkan Masalah dan Hasil Belajar Kognitif Siswa Biologi SMA. JPS (Jurnal Pendidikan Sains), 4(2), 60-64. https://doi.org/10.17977/jps.v4i2.8183

Suprapto, E. (2017). Pengaruh Model Pembelajaran Kontekstual, Pembelajaran Langsung Dan Motivasi Berprestasi Terhadap Hasil Belajar Kognitif. Innovation of Vocational Technology Education, 11(1), 23-40. https://doi.org/10.17509/invotec.v11i1.4836

Susiana, R., \& Wening, S. (2015). Pengaruh Model Direct Instruction Berbantuan Multimedia Terhadap Motivasi Belajar Dan the Effect of Multimedia - Aided Direct Instruction on the Learning Motivation for Achievement in the. Jurnal Pendidikan Vokasi, 3(1), 377-393.

Ulya, I. F., \& Irawati, R. (2016). Peningkatan Kemampuan Koneksi Matematis Dan Motivasi Belajar Siswa Menggunakan Pendekatan Kontekstual. Jurnal Pena Ilmiah, 1(1), 121-130. https://doi.org/10.23819/pi.v1i1.2940

Usman, F. A., \& Afriansyah, E. A. (2017). Kemampuan Pemahaman Matematis Siswa Melalui Model Pembelajaran Auditory Intellectualy Repetition Dan Problem Based Learning (Studi Penelitian di SMP Negeri 1 CisurupanKelas VII). Jurnal Pendidikan Matematika, 11(1), 68. https://doi.org/http://dx.doi.org/10.22342/jpm.11.1.3890.67-78

Widodo, \& Widayanti, L. (2014). Peningkatan Aktivitas Belajar dan Hasil Belajar Siswa dengan Metode Problem Based Learning pada Siswa Kelas VIIA MTs Negeri Donomulyo Kulon Progo Tahun Pelajaran 2012/2013. Jurnal Fisika Indonesia, 17(49), 32-35. https://doi.org/10.22146/jfi.24410 